\title{
p53 Protein and Proliferating Cell Nuclear Antigen (PCNA) Expression in Small Round Cell Tumors of Bone and Adjacent Soft Tissue
}

\author{
A Study of 60 Cases
}

\author{
Kenneth Devaney, M.D.,* Susan L. Abbondanzo, M.D., ${ }^{\dagger}$ \\ Kris M. Shekitka, M.D., ${ }^{\ddagger}$ Robert B. Wolov, M.D., ${ }^{\dagger}$ \\ and Donald E. Sweet, M.D..$^{\ddagger}$
}

\begin{abstract}
Sixty small cell tumors of bone and adjacent soft tissue were studied in an attempt to define the incidence of immunohistochemically detectable $\mathrm{p} 53$ protein and correlate these findings with the results of proliferating cell nuclear antigen (PCNA) immunohistochemical staining and mitotic counts. All of the lesions had been formalin-fixed and paraffin-embedded; half were subjected to decalcification prior to processing. The study population included 12 Ewing's sarcomas of bone, 3 atypical Ewing's sarcomas of bone, 3 primitive neuroectodermal tumors of bone, 11 Askin tumors of the thoracopulmonary region, 11 small cell osteosarcomas of bone, 10 mesenchymal chondrosarcomas of bone, and 10 malignant lymphomas involving bone. The patients ranged in age at the time of presentation from 17 to 67 years. Overall, the incidence of p53 positivity was extremely low in these lesions, irrespective of tumor type. Positive nuclear staining with an antibody to $\mathrm{p} 53$ was found in none of the 12 Ewing's sarcomas, none of the 3 atypical Ewing's sarcomas, none of the 3 primitive neuroectodermal tumors of bone, 1 of the 11 Askin tumors of the thoracopulmonary region ( $1.5 \%$ of tumor cells positive), 1 of the 11 small cell osteosarcomas ( $2 \%$ of tumor cells positive), 1 of the 10 mesenchymal chondrosarcomas of bone ( $7 \%$ of tumor cells positive), and 2 of the 10 malignant lymphomas involving bone $(0.5 \%$ and $1 \%$ of tumor cells positive, respectively). The majority of tumors showed PCNA positivity within the tumor cells, although the incidence of PCNA positivity within the histologic types varied greatly; in general, the higher PCNA counts corresponded to higher mitotic counts within the individual lesions. The present study did not demonstrate any correlation between mutant p53 accumulation detected by immunohistochemistry and tumor type, and so it is unlikely that $\mathrm{p} 53$ positivity will prove to be of great use in the differential diagnosis of these lesions. A correlation between $\mathrm{p} 53$ positivity and PCNA staining or mitotic activity was not apparent. Int J Surg Pathol 2(4):259-268, 1995
\end{abstract}

Key words: Ewing's sarcoma, Askin tumor, neuroectodermal tumor, mesenchymal chondrosarcoma, small cell osteosarcoma, lymphoma, p53, PCNA.

From "the Departments of Pathology and Orthopaedic Surgery, Brown University, Rhode Island Hospital, Providence, Rhode Island, and the Department of Pathology, University of Michigan, Ann Arbor, Michigan; the Division of Immunohistochemistry, Armed Forces Institute of Pathology, Washington, DC; and the Department of Orthopedic Pathology, Armed Forces Institute of Pathology, Washington, DC.

Received for publication Feb. 23, 1994; accepted in revised form Nov. 9, 1994.

Reprint requests: Kenneth Devaney, M.D., Department of Pathology 2G332/0054, University of Michigan, 1500 E Medical Center Drive, Ann Arbor, MI 48109-0054. 
The introduction of new technologies into the practice of diagnostic pathology often invites a reexamination of what previously were challenging diagnostic problems in the hope of better defining diagnostic or prognostic criteria. The potential diagnostic dilemma presented by the "small round cell tumor of bone" is a classic example of this problem that is faced by the surgical pathologist in routine practice. Only recently, with the introduction of newer investigative modalities, such as antibodies directed against the HBA71 antigen and fluorescent in situ hybridization for detection of the cytogenetic abnormality $t(11 ; 22)$ for the prospective identification of the Ewing's sarcoma or primitive neuroectodermal tumor family lesions (often taken to include typical and atypical Ewing's sarcoma, the Askin tumor of the thoracopulmonary region, and primitive neuroectodermal tumors of bone and soft tissue), have great strides been made in addressing this vexing problem for the diagnostic pathologist. ${ }^{1,2}$

The present study was undertaken to determine the incidence of nuclear p 53 protein positivity by immunohistochemical means in a large group of small cell bone lesions and to explore the potential application of these lindings to the differential diagnosis and prognosis of these lesions. At the same time, proliferating cell nuclear antigen (PCNA) immunostaining of the lesions and calculation of the mitotic counts were carried out for correlation with the p53 results. In view of the ready availability of immunohistochemical techniques to the diagnostic surgical pathologist (and, conversely, the difficulty at present in carrying out sophisticated molecular studies in many hospitals), immunohistochemical staining for the presence of an antigen such as p53 might provide valuable prognostic, diagnostic, or therapeutic information, which may serve as a clinical assay for use in the general pathologist's practice.

\section{Materials and Methods}

Sixty biopsies of small cell lesions of bone and adjacent soft tissue were drawn from the consultation files of the Armed Forces Institute of Pathology and the Rhode Island Hospital. Twenty-nine of the cases were the subject, in part, of an earlier report of the immunohistochemical features of small round cell tumors of bone. ${ }^{3}$ The remaining cases were collected both prospectively and from the archives of the Armed Forces Institute of Pathology and the Rhode Island Hospital; the oldest cases (embedded in paraffin) dated back to the 1960s.

In each instance, hematoxylin and eosin-stained sections were available for study; in many cases, periodic acid-Schiff-stained sections (both with and without diastase pretreatment) were available as well. Some of the lesions had been studied ultrastructurally, but this was not the focus of the present report and so was not uniformly employed in all of the study cases. The final diagnosis in each of the 60 study cases was based on the light microscopic features of the individual lesions, employing criteria that have been previously reported. ${ }^{3}$

The study population consisted of 12 classic osseous Ewing's sarcomas (Fig. 1), 3 atypical osseous Ewing's sarcomas, 3 primitive neuroectodermal tumors of bone (Fig. 2), 11 Askin tumors of the thoracopulmonary region (Fig. 3), 11 small cell osteosarcomas of bone (Fig. 4), 10 mesenchymal chondrosarcomas of bone (Fig. 5), and 10 malignant lymphomas involving bone. The patients ranged in age at the time of presentation from 17 to 67 years.

All tissues studied by immunohistochemistry had been formalin-fixed and paraffin-embedded; approximately half had been subjected to decalcification prior to processing (by a variety of methods). Five of the Ewing's sarcomas, 5 of the mesenchymal chondrosarcomas, 4 of the Askin tumors, 3 of the small cell osteosarcomas, and 4 of the lymphomas consisted of lesions in which both decalcified and undecalcified tumor blocks were available; in these 21 tumors, a comparison between decalcified and undecalcified specimens with regard to differences in the incidence of either p53 or PCNA immunostaining was performed. The antibody to p53 was a polyclonal antibody to mutant type p53 (CMl, Novocastra Laboratories, Newcastle upon Tyne; diluted 1:400), while the antibody to PCNA was a

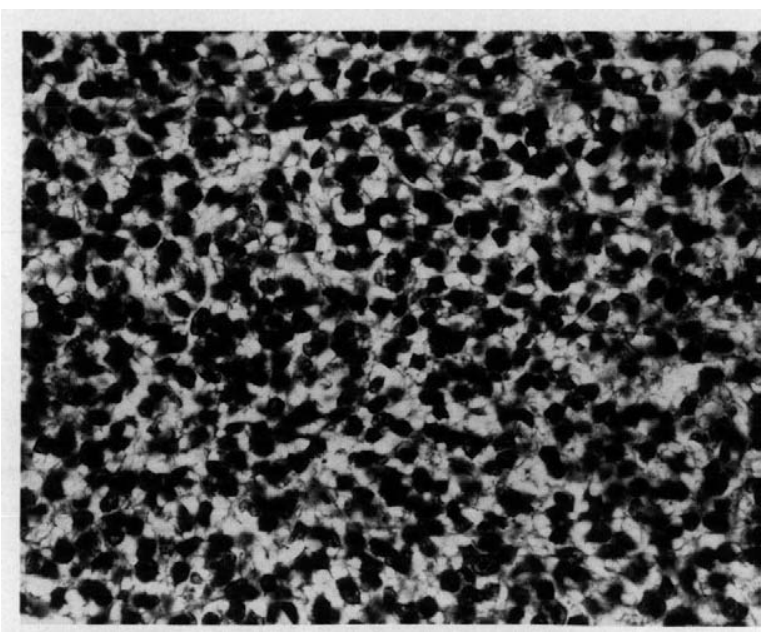

Fig. 1. The classic Ewing's sarcoma is marked by a sheetlike proliferation of relatively uniform small round cells, often with clear to finely vacuolated cytoplasm and small nuclear chromocenters (hematoxylin and eosin, original magnification $\times 220$ ). 


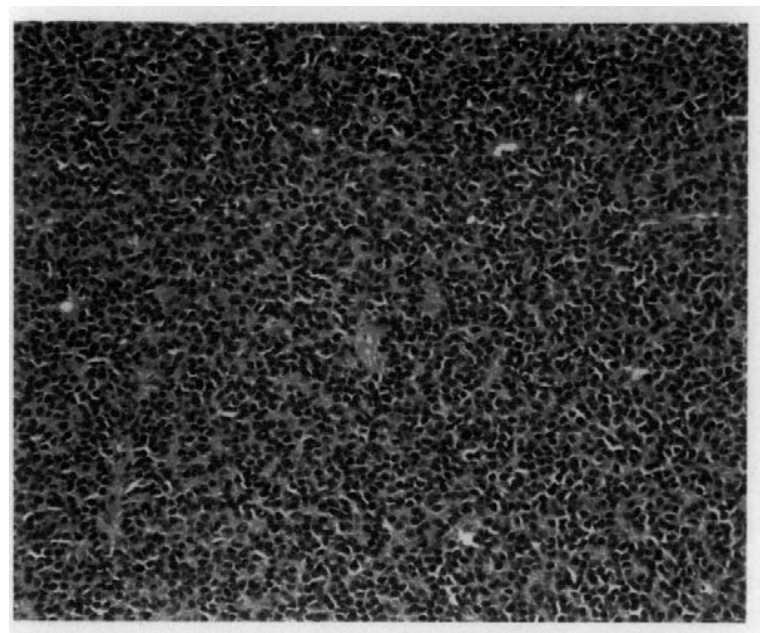

Fig. 2. Peripheral neuroectodermal tumor of bone was defined by light microscopy as a lesion composed of sheets of cells similar to those of Ewing's sarcoma but with the added architectural requirement that more than half of the tissue showed evidence of pseudorosette formation (formation of true rosettes was not noted) (hematoxylin and eosin, original magnification $\times 120$ ).

monoclonal preparation (Dako Corp., Carpenteria, CA; diluted 1:500). Sections were developed using a modified avidin-biotin-peroxidase complex technique. ${ }^{4}$ Controls used within each run included positive and negative control tissues; formalin-fixed, paraffin-embedded colonic adenocarcinoma served as the positive control for $\mathrm{p} 53$ staining (over $90 \%$ of the tumor cells were consistently positive), while negative controls consisted of a section of each tumor being studied with substitution of nonimmune rabbit serum for the primary antibody. Antigen retrieval was carried out by heating

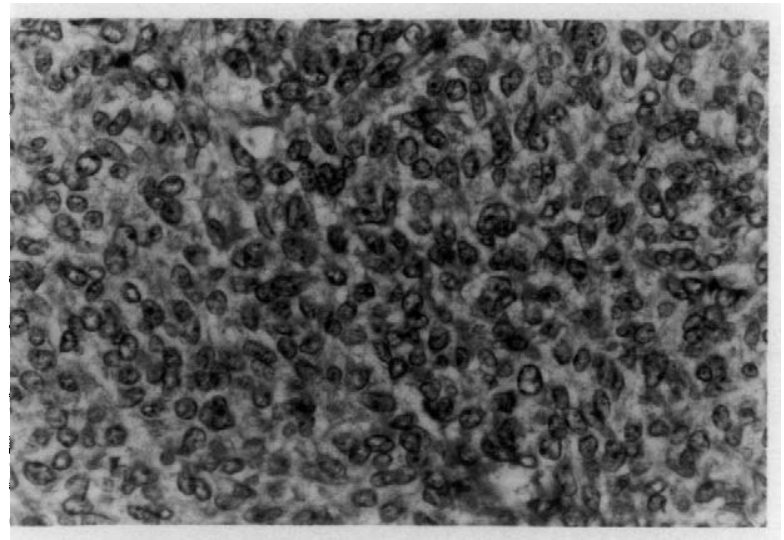

Fig. 3. The component cells of the Askin tumors of the thoracopulmonary region resembled Ewing's sarcoma cells in many lesions, with a somewhat greater tendency toward elongation of the nuclei in some areas (hematoxylin and eosin, original magnification $\times 220$ ).

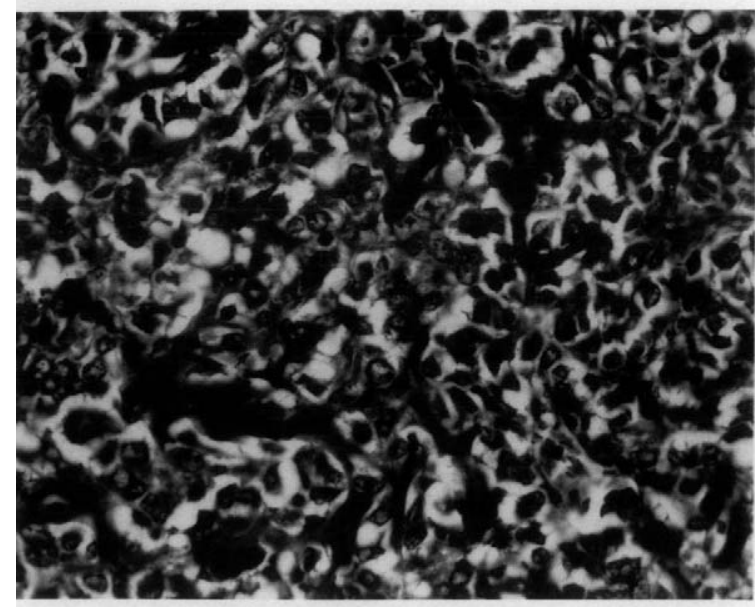

Fig. 4. The small cell osteosarcomas were characterized by a proliferation of hyperchromatic round to oval tumor cells that often exhibited a greater degree of nuclear pleomorphism than was seen in the classic Ewing's sarcomas; formation of osteoid by the tumor cells (as seen here) was found only focally (hematoxylin and eosin, original magnification $\times 220$ ).

deparaffinized tissue sections for 10 minutes in a solution of citrate buffer. A microwave oven was employed as a source of heating for this process.

In each case, 200 tumor cells were counted, and the presence or absence of positive nuclear staining with antibody to p53 and to PCNA was noted. In cases in which a variable degree of staining was appreciated within the specimen, counting was done in the most intensely stained zone. The percentage of positive cells was recorded in each

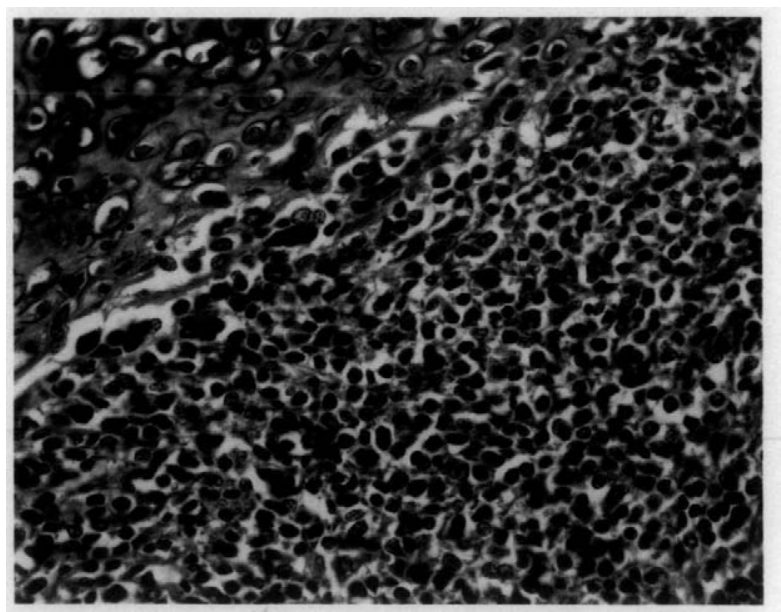

Fig. 5. A juxtaposition of two components (islands of cartilage embedded in a sea of hyperchromatic small round to oval cells) typified the mesenchymal chondrosarcomas of bone (hematoxylin and eosin, original magnification $\times 220$ ). 
instance. Within the same region, the number of mitotic figures was counted in 20 high-power fields (HPF) (Olympus microscope, $40 \times$ objective and $10 \times$ ocular lens, field area $0.159 \mathrm{~mm}^{2}$ ) and recorded as mitoses per $10 \mathrm{HPF}$.

\section{Results}

Positive nuclear staining with an antibody to p53 was found in none of the 12 Ewing's sarcomas, none of the 3 atypical Ewing's sarcomas, none of the 3 primitive neuroectodermal tumors of bone, 1 of the 11 Askin tumors of the thoracopulmonary region $(1.5 \%$ of tumor cells positive), 1 of the 11 small cell osteosarcomas $(2 \%$ of tumor cells positive) (Fig. 6), 1 of the 10 mesenchymal chondrosarcomas of bone ( $7 \%$ of tumor cells positive) (Fig. 7), and 2 of the 10 malignant lymphomas involving bone $10.5 \%$ and $1 \%$ of tumor cells positive, respectively).

Some degree of PCNA positivity was found in the majority of tumors studied, irrespective of the histologic subtype; however, within each histologic type, a wide variation in the percentage of positive cells was seen. Specifically, 10 of 12 Ewing's sarcomas were PCNA positive (range, $1 \%$ to $92 \%$ of tumor cells positive, mean 29\%) (Fig. 8); 2 of 3 atypical Ewing's sarcomas were PCNA positive (5\% and $94 \%$ of tumor cells positive, respectively); 2 of 3 primitive neuroectodermal tumors of bone were PCNA positive $(1 \%$ and $13 \%$ of tumor cells positive, respectively); 11 of 11 Askin tumors of the thoracopulmonary region were PCNA positive (range, $12 \%$ to $94 \%$ of tumor cells positive, mean $43 \%) ; 10$ of 11 small cell osteosarcomas were PCNA positive (range, $1 \%$ to $88 \%$ of tumor cells

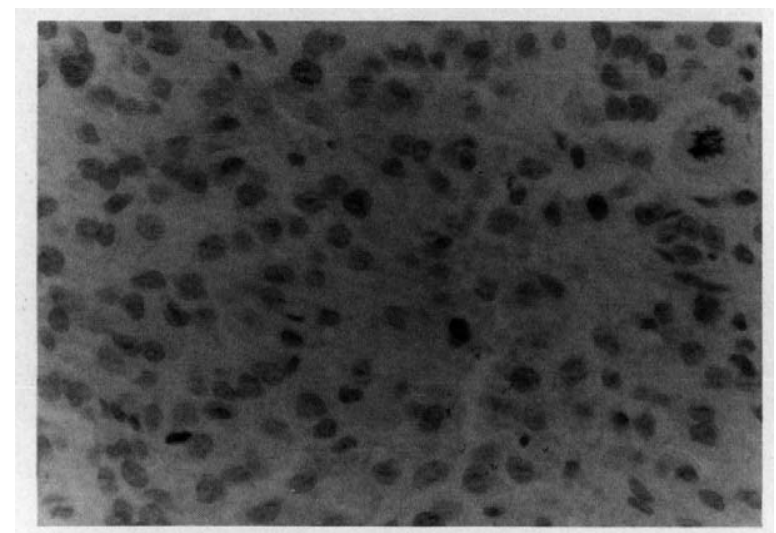

Fig. 6. Immunostaining of this small cell osteosarcoma with antibody to p53 yielded only rare positive cells (center of figure) (antibody to p53, hematoxylin counterstain, original magnification $\times 220$ ).

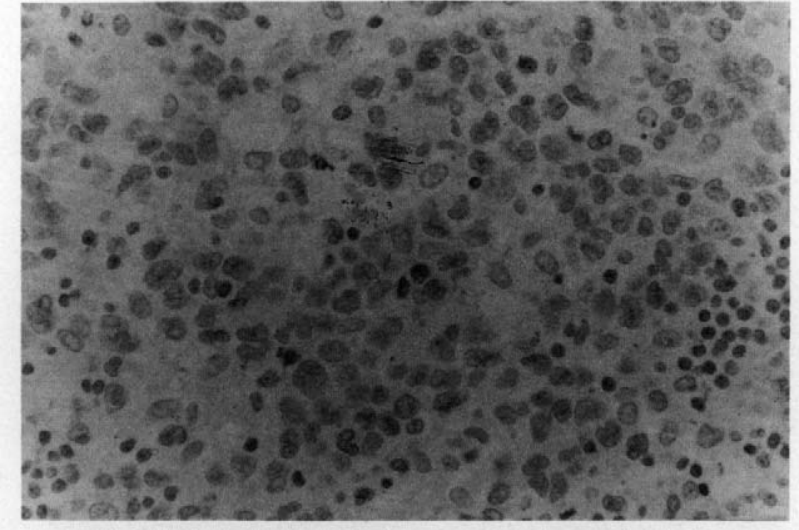

Fig. 7. Immunostaining of this malignant lymphoma of bone with antibody to $\mathrm{p} 53$ yielded only rare positive tumor cells (antibody to p53, hematoxylin counterstain, original magnification $\times 220$ ).

positive, mean $34 \%$ ); 9 of 10 mesenchymal chondrosarcomas of bone were PCNA positive (range, $2 \%$ to $66 \%$ of tumor cells positive, mean $19 \%$ ); and 9 of 10 malignant lymphomas involving bone were PCNA positive (range, $1 \%$ to $87 \%$ of tumor cells positive, mean $41 \%$ ).

The highly variable degree of PCNA positivity within the individual tumor types corresponded to the variable mitotic count within the lesional types studied. The Ewing's sarcomas of bone had from 1 to 18 mitoses/ $10 \mathrm{HPF}$; the atypical Ewing's sarcomas had from 2 to 11 mitoses/ $10 \mathrm{HPF}$; the primitive neuroectodermal tumors had from 1 to 7 mitoses/10

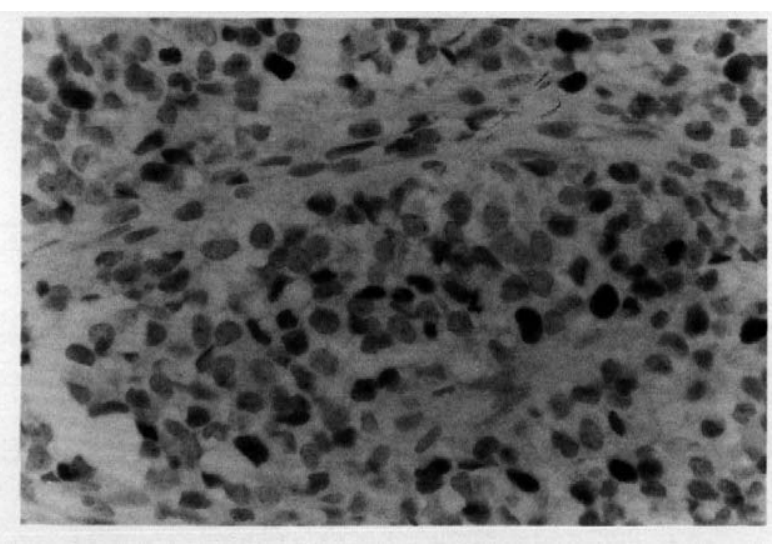

Fig. 8. Immunostaining with antibody to proliterating cell nuclear antigen (PCNA) yielded some degree of positive nuclear staining in the majority of the tumors studied, although the proportion of positive cells varied greatly from one lesion to another; shown here is a classic Ewing's sarcoma of bone in which approximately $35 \%$ of the tumor cells were PCNA positive (antibody to $P C N A$, original magnification $\times 220$ ). 
HPF; the Askin tumors of the thoracopulmonary region had from 2 to 28 mitoses/ $10 \mathrm{HPF}$; the small cell osteosarcomas had from 3 to 38 mitoses/10 HPF; the mesenchymal chondrosarcomas of bone had from 1 to 9 mitoses/10 HPF; and the malignant lymphomas involving bone had from 4 to 18 mitoses/10 HPF.

A direct correspondence between an increasing level of PCNA positivity and the mitotic count was noted in this study; this correspondence (that is, the finding of a high percentage of PCNA positive tumor cells in a given tumor usually predicted a higher mitotic rate within that lesion) was found irrespective of the histologic group of tumor studied.

No relationship was seen between the rare p53 positive tumors in each group and either the percentage of PCNA positive cells or the mitotic counts; that is, p53 positivity did not correspond either to a strikingly high or strikingly low rate of PCNA positivity or mitotic activity.

Previous decalcification did not produce an appreciable effect on the incidence or quantity of PCNA staining. The impact of prior decalcification on p53 immunostaining was more difficult to judge, in view of the extremely low incidence of p53 staining found in the study population overall.

\section{Discussion}

The present study found a consistently low incidence of positive nuclear staining of tumor cells with antibody to mutant p53 in a variety of small cell lesions of bone, including the Ewing's/primitive neuroectodermal family of tumors, small cell osteosarcoma, and mesenchymal chondrosarcoma. To place these observations in context, Table 1 includes a tabulation of selected reports on the incidence of positive immunohistochemical staining of tumor cell nuclei in a variety of musculoskeletal tumors as well as the findings of the present investigation. ${ }^{5-13}$

It has been established that, among the tumor suppressor genes that have been characterized to date, abnormalities involving the p53 gene (also known as the TP53 gene) are extremely common in a host of different human tumor types. ${ }^{14-30}$ The normal p53 gene (located on the short arm of chromosome 17) plays a role in the regulation of a cell's entry into the $S$ phase, producing a nuclear phosphoprotein (the wild-type $\mathrm{p} 53$ protein) that acts to interfere with the transcription of DNA and so impedes cell proliferation. In experimental systems, the wild-type $\mathrm{p} 53$ protein has been shown to slow or even inhibit altogether cellular transformation by oncogenes. ${ }^{18}$ Inactivation of the p53 gene may result either from deletion of the gene or from its mutation. The precise mechanisms are extremely complex and continue to be incompletely understood; however, it is known that a variety of different mutations may affect the p 53 gene in different tumor types. ${ }^{17,18}$ The phenomenon of $\mathrm{p} 53$ alteration has been best studied in large intestinal adenocarcinomas, in which a majority of tumors exhibit a loss of one p53 allele via mutation and a loss of the other $\mathrm{p} 53$ allele through deletion. ${ }^{17,18}$

Table 1. Frequency of p53 Positivity by Immunohistochemistry in Musculoskeletal Tumors

\begin{tabular}{lll}
\hline Tumor Type & Location & Frequency of p53 Positivity \\
\hline Osteosarcoma (not further subclassified) & Bone & Common \\
Small cell osteosarcoma & Bone & Rare \\
Chondrosarcoma (not further subclassified) & Bone & Uncommon \\
Mesenchymal chondrosarcoma & Bone & Rare \\
Malignant fibrous histiocytoma & Bone & Rare \\
Giant cell tumor & Bone & Rare/uncommon \\
Ewing's sarcoma/PNET family tumors & Bone & Rare \\
Malignant fibrous histiocytoma & Soft tissue & Uncommon \\
Atypical fibroxanthoma & Soft tissue & Common \\
Liposarcoma & Soft tissue & Uncommon \\
Rhabdomyosarcoma & Soft tissue & Common \\
Leiomyosarcoma & Soft tissue & Common \\
Malignant peripheral nerve sheath tumor & Soft tissue & Common \\
Adult fibrosarcoma & Soft tissue & Rare/uncommon \\
Congenital/infantile fibrosarcoma & Soft tissue & Common \\
Fibromatosis & Soft tissue & Rare \\
Dermatofibrosarcoma protuberans & Soft tissue & Rare \\
Nodular fasciitis & Soft tissue & Rare \\
Malignant mesothelioma & Soft tissue & Common \\
Angiosarcoma & Soft tissue & Common \\
Pyogenic granuloma & Soft tissue & Common \\
\hline
\end{tabular}

PNET, peripheral primitive neuroectodermal tumor; rare, reported in less than $10 \%$ of tumors of this type; uncommon, reported in $10 \%$ to $30 \%$ of tumors of this type; common, reported in more than $30 \%$ of tumors of this type. 
With regard to the present study, the failure of an appreciable number of the small cell osteosarcomas to stain with antibody to the p53 protein is somewhat at odds with the expected results as might have been predicted by the reports describing the finding of relatively frequent mutations of the $\mathrm{p} 53$ gene in osteosarcomas with accompanying p 53 protein accumulation by immunohistochemistry, as noted in Table $1 .{ }^{6,7}$ This may simply reflect the occasional lack of close correlation between these two parameters, as has been hinted at in other tumor types. It has been noted in some tumors, including some hematopoietic and hepatic neoplasms, that the incidence of $\mathrm{p} 53$ protein overexpression may exceed the incidence of p53 gene mutations. ${ }^{31-33}$ Such an apparent discrepancy may indicate accumulation of a nonmutated p53 protein (particularly likely when the antibody employed recognizes epitopes on both wild-type and mutant p53 protein), or even crossreactivity of the antibody with other nuclear components than the $\mathrm{p} 53$ protein itself.

Moreover, despite a finding of p53 mutation (as detected by polymerase chain reaction) in some sarcomas, the corresponding production of a protein detectable by immunohistochemistry is not always observed. ${ }^{7}$ Such an occurrence may reflect the presence of a p53 gene mutation that produces not a missense mutation, which typically yields a detectable increase in nuclear p53 protein by immunohistochemistry, but that results in a nonsense mutation or even a gross deletion of the gene. In addition, failure of immunohistochemistry to detect $\mathrm{p} 53$ protein accumulation may correspond to technical inadequacies within the tissue, such as over- or underfixation. Others have observed that, while p53 mutations are usually not found in primary tumor samples of Ewing's sarcoma, cell lines derived from those same tumors often will show evidence of p53 gene mutation, reflecting, perhaps, some survival advantage conferred in the culture environment by the mutation. ${ }^{34,35}$

Such observations raise questions about the reliability of p53 immunostaining as a marker for detectable mutations of the p53 gene in at least some mesenchymal tumors. It may prove to be that (in contrast to many carcinomas) some sarcomas either do not show frequent $\mathrm{p} 53$ gene mutations, or these mutations may fail to result in the production of a protein product not detectable by presently employed techniques. To date, mutations of the p53 gene have been identified less frequently in sarcomas than in epithelial malignancies; among the two mesenchymal tumor types that do exhibit an appreciable frequency of $\mathrm{p} 53$ mutation by gene sequencing are rhabdomyosarcomas and osteosar- comas. ${ }^{19,36,37}$ Apparent overexpression of the p53 protein product (manifested as positive immunohistochemical staining) has been reported in an admixture of non-neoplastic, benign, and malignant soft tissue lesions, suggesting that further studies are required to explain these findings. ${ }^{9}$

The present investigation employed a widely used antibody directed toward mutant p 53 protein, the CMl polyclonal antibody. As in all immunohistochemical investigations, our study is subject to variations that may have been produced by a number of potential variables, including type of tissue fixative employed, length of fixative exposure, and varying sensitivities and specificities among the various commercially available antisera. The potential influence of these and other variables must be borne in mind when interpreting the results of an immunohistochemical study such as ours. Antigen retrieval was employed in an attempt at minimizing the impact of these potentially confounding factors.

This study of paraffin-embedded tissues did not permit either comparison of frozen with fixed tissue sections or of decalcified with undecalcified tissues within the same tumor in each instance. Five of the Ewing's sarcomas, 5 of the mesenchymal chondrosarcomas, 4 of the Askin tumors, 3 of the small cell osteosarcomas, and 4 of the lymphomas consisted of lesions in which a portion of the tumor had been decalcified and a portion had not. In these 21 tumors, a comparison between decalcified and undecalcified specimens did not yield an appreciable difference in the incidence of either p53 or PCNA immunostaining, suggesting that decalcification does not appear to have an appreciable effect on these results.

Although an estimation of a tumor's mitotic activity has classically been cited as an index of that tumor's proliferative activity (and hence, presumably, provides some insight into the degree of aggressiveness of that tumor as an independent histologic parameter), it has been suggested by some observers that this is not necessarily always the case. Mitosis counting has been criticized as lacking in reproducibility among different (and even the same) observers, subject to variation as a function of tissue processing, and simply lacking significance in strict follow-up studies of certain tumor types. ${ }^{38-46}$

In light of the above considerations, attempts have been made at identifying alternate methods of assessing proliferative activity, methods that would prove to be both reproducible and statistically significant. These alternative approaches may be divided into two broad groups: first, the more technically difficult or expensive methods, which 
include the use of flow cytometry, tritiated thymidine, and bromodeoxyuridine; and second, the less involved/or expensive methods, including immunohistochemical staining for $\mathrm{Ki}-67$ and PCNA. With regard to PCNA staining in particular, some significance for PCNA staining (either as a diagnostic or as a prognostic tool) has been reported in such disparate lesions as hepatocellular tumors, epithelial-myoepithelial carcinoma of salivary gland origin, mast cell disease, endometrial adenocarcinoma, renal carcinoma, synovial sarcoma, and dysplastic bronchial epithelium. ${ }^{47-54}$

As was the case with p53 immunostaining, questions have arisen with regard to the specificity of the various antibody preparations available for identifying PCNA, as well as the potentially confounding influences that may be provided by such factors as type and length of fixation employed and other technical variables..$^{55-63}$ In general, PCNA labeling increases as the mitotic count within the tissue section increases. ${ }^{64}$ This was seen in our series of small cell tumors of bone as well. Separate groups of lesions (distinct, that is, from groups that might have been delineated based on mitotic activity alone) were not distinguished by PCNA staining results.

The present study did not demonstrate any correlation between nuclear $\mathrm{p} 53$ protein accumulation as detected by immunostaining and tumor type, and so it is unlikely that $\mathrm{p} 53$ positivity will prove to be of great use in the differential diagnosis of these lesions. A correlation between $\mathrm{p} 53$ positivity and PCNA staining or mitotic activity was likewise not apparent. While follow-up data on our material is limited, the rare p53 positive tumors did not appear to exhibit an unusually aggressive or unusually indolent course when compared with the $\mathrm{p} 53$ negative lesions.

Among the avenues open for future exploration is the relationship of the protein product of the murine double minute-2 gene (MDM2 gene located on the long arm of chromosome 12) to p53 gene mutation. Some have suggested that MDM2 amplification may inactivate the same regulatory pathway as does p53 mutation. It appears that these two mechanisms may act, at least in mesenchymal tumors, exclusively of one another, that is, preliminary findings suggest that a given sarcoma may exhibit either p53 mutation or MDM2 amplification but usually not both. ${ }^{65-67}$ It has been suggested that those infrequent sarcomas exhibiting both p53 mutation and MDM2 amplification may follow a more aggressive course than those harboring only one of these abnormalities. ${ }^{66}$ Confirmation of these observations promises to yield further insights into the genesis and progression of tumors of mesenchymal tissues.

\section{References}

1. Fellinger EJ, Garin-Chesa P, Glasser DB, Huvos AG, Rettig WJ. Comparison of cell surface antigen HBA71 (p30/32 ${ }^{\mathrm{MIC}^{3}}$ ), neuron-specific enolase, and vimentin in the immunohistochemical analysis of Ewing's sarcoma of bone. Am J Surg Pathol $16: 746-755,1992$

2. Taylor C, Patel K, Jones T, Kiely F, De Stalvo BL, Sheer D. Diagnosis of Ewing's sarcoma and peripheral neuroectodermal tumour based on detection of $\mathrm{t}(11 ; 22)$ using fluorescent in situ hybridization. Br J Cancer 67:128-133, 1993

3. Devaney K, Vinh TN, Sweet DE. Small cell osteosarcoma of bone-An immunohistochemical study with differential diagnostic considerations. Hum Pathol 24:1211-1225, 1993

4. Hsu SM, Raine L, Fanger H. Use of avidin-biotin-peroxidase complex $(\mathrm{ABC})$ in immunoperoxidase techniques: A comparison between $\mathrm{ABC}$ and unlabelled antibody procedures. J Histochem Cytochem 29:577-580, 1981

5. Soini Y, Vähägangas K, Nuorva K, Kamel D, Lane DP, Pääkkö P. p53 immunohistochemistry in malignant fibrous histiocytomas and other mesenchymal tumours. J Pathol 168:29-33, 1992

6. Ueda X, Dockhorn-Dworniczak B, Blasius S, Mellin W, Wuisman P, Böcker W, Roessner A. Analysis of mutant p53 protein in osteosarcomas and other malignant and benign lesions of bone. $\mathrm{J}$ Cancer Res Clin Oncol I 19:172-178, 1993

7. Wadayama B, Toguchida J, Yamaguchi T, Sasaki MS, Kotoura Y, Yamamuro T. p53 expression and its relationship to DNA alterations in bone and soft tissue sarcomas. Br J Cancer 68:1 134-1 139, 1993

8. Kawai A, Noguchi M, Beppu Y, Yokoyama R, Mukai $\mathrm{K}$, Hirohashi S, Inoue $\mathrm{H}$, Fukuma $\mathrm{H}$. Nuclear immunoreaction of $\mathrm{p} 53$ protein in soft tissue sarcomas-A possible prognostic factor. Cancer 73:2499-2505, 1994

9. Dei Tos AP, Doglioni C, Laurino L, Barbareschi $M$, Fletcher CDM. p53 protein expression in nonneoplastic lesions and benign and malignant neoplasms of soft tissue. Histopathol 22:45-50, 1993

10. Patterson H, Gill S, Fisher C, Law MG, Jayatilake H, Fletcher CDM, Thomas M, Grimer R, Gusterson BA, Cooper CS. Abnormalities of the p53 MDM2 and DCC genes in human leiomyosarcomas. $\mathrm{Br} \mathrm{J}$ Cancer 69:1052-1058, 1994

11. Inohara S. Immunohistochemical localization of $\mathrm{p} 53$ protein in malignant hemangioendothelioma. Acta Derm Venereol (Stockh) 74:161-162, 1994

12. Oshiro Y, Fukada T, Tsuneyoshi M. Fibrosarcoma versus fibromatoses and cellular nodular fasciitisa comparative study of their proliferative activity using proliferating cell nuclear antigen, DNA flow cytometry, and p53. Am J Surg Pathol 18: 712-719, 1994

13. Mayall FG, Goddard $H$, Gibbs AR. The frequency of $p 53$ immunostaining in asbestos-associated mesothe- 
liomas and non-asbestos-associated mesotheliomas. Histopathol 22:383-386, 1993

14. Bourhis J. Oncogenes and tumor suppressor genes in human cancers: Clinical implications. Br J Radiol 24 (Suppl):215-219, 1993

15. Hall EJ. Review article: The gene as theme in the paradigm of cancer. Br J Radiol 66:1-11, 1993

16. Yandell DW, Thor AD. p53 analysis in diagnostic pathology-Biologic implications and possible clinical applications. Diagn Molec Pathol 2:1-3, 1993

17. Hollstein M, Sidransky D, Vogelstein B, Harris CC. p53 mutations in human cancers. Science 253:49-53, 1991

18. Levine AJ, Momand J, Finlay CA. The p53 tumour suppressor gene. Nature 351:453-456, 1991

19. Malkin D, Li FP, Strong LC, Fraumenz JF, Nelson CE, Kim DH, Kassel J, Gryka MA, Bischoff FZ, Tainsky MA, Friend SH. Germ line p53 mutations in a familial syndrome of breast can-cer, sarcomas, and other neoplasms. Science 250:1233-1238, 1990

20. McKenzie SJ. Diagnostic utility of oncogenes and their products in human cancer. Biochem Biophys Acta 1072:193-214, 1991

21. Sidransky D, Von Eschenbach A, Tsai YC, Jones $P$, Summerhayes I, Marshall F, Paul M, Green P, Hamilton SR, Frost P, Vogelstein B. Identification of $\mathrm{p} 53$ gene mutations in bladder cancers and urine samples. Science 252:706-709, 1991

22. Tamura G, Kihana T, Nomura $K$, Terada $M$, Sugimura $T$, Hirohashi $S$. Detection of frequent p53 gene mutations in primary gastric cancer by cell sorting and polymerase chain reaction single-strand conformation polymorphism analysis. Cancer Res 51:3056-3058, 1991

23. Chiba I, Takahashi T, Nau MM, D'Amico D, Curiel DT, Mitsudomi T, Buchhagen DL, Carbone D. Pinatadosi S, Koga H, Reissman PT, Slamon DJ, Holmes EC, Minna JD. Mutations in the p53 gene are frequent in primary, resected non-small cell lung cancers. Oncogene 5:1603-1610, 1990

24. Prosser J, Thompson AM, Cranston G, Evans HJ. Evidence that $\mathrm{p} 53$ behaves as a tumour suppressor gene in sporadic breast tumours. Oncogene 5:1573-1579, 1990

25. Paquette RL, Lee YY, Wilczynski SP, Karmakar A, Kizaki M, Miller CW, Kowffler HP. Mutations of p53 and human papillomavirus infection in cervical carcinoma. Cancer 72:1272-1280, 1993

26. Joypaul BV, Newman EL, Hopwood D, Grant A, Qureshi S, Lane DP, Cuschieri A. Expression of p53 protein in normal, dysplastic, and malignant gastric mucosa: An immunohistochemical study. J Pathol 170:279-283, 1993

27. Niedobitek G, Agathanggelou A, Barber P, Smallman LA, Jones EL, Young LS. p53 overexpression and Epstein-Barr virus infection in undifferentiated and squamous cell nasopharyngeal carcinomas. J Pathol 170:457-461, 1993
28. Casson AG, Mukhopadhyay T, Cleary KR, Ro JY, Levin B, Roth JA. p53 gene mutations in Barrett's epithelium and esophageal cancer. Cancer Res 51:4495-4499, 1991

29. Soini Y, Kamel D, Nuorva K, Lane DP, Vähäkangas K, Pääkkö $\mathrm{P}$. Low $\mathrm{p} 53$ protein expression in salivary gland tumours compared with lung carcinomas. Virch Arch A Pathol Anat 421:415-420, 1992

30. Ng H-K, Lo K-W, Huang DP, Poon W-S. p53 in lowgrade gliomas. Int J Surg Pathol 1:163-170, 1994

31. Cesarman E, Inghirami G, Chadburn A, Knowles DM. High levels of p53 protein expression do not correlate with p53 gene mutations in anaplastic large cell lymphoma. Am J Pathol 143:485-856, 1993

32. Matsushima AY, Cesarman E, Chadburn A, Knowles DM. Post-thymic $\mathrm{T}$ cell lymphomas frequently overexpress $\mathrm{p} 53$ protein but infrequently exhibit p53 gene mutations. Am J Pathol 144:573-584, 1994

33. Kennedy SM, Macgeogh C, Jaffe R, Spurr NK. Overexpression of the oncoprotein p53 in primary hepatic tumors of childhood does not correlate with gene mutations. Hum Pathol 25:438-442, 1994

34. Kovar H, Auinger A, Jug G, Aryee D, Zoubek A, Salzerkuntschik M, Gadner H. Narrow spectrum of infrequent p53 mutations and absence of MDM2 amplification in Ewing tumours. Oncogene 8:2683-2690, 1993

35. Komuro $H$, Hayashi $Y$, Kawamura $M$, Hayashi $K$, Kaneko Y, Kamoshita S, Hanada R, Yamamoto K, Hongo T, Yamada $M$. Tsuchida Y. Mutations of the p53 gene are involved in Ewing's sarcomas but not in neuroblastomas. Cancer Res 53:5284-5288, 1993

36. Mulligan LM, Matlashewski GJ, Scrable HJ, Cavenee WK. Mechanisms of p53 loss in human sarcomas. Proc Natl Acad Sci USA 87:5863-5867, 1990

37. Boman F, Peters $J$, Ragge $N$, Triche $T$. Infrequent mutations of the p53 gene in fibrous tumors of infancy and childhood. Diagn Molec Pathol 2:14-22, 1993

38. Silverberg SG. Reproducibility of the mitosis count in the histologic diagnosis of smooth muscle tumors of the uterus. Hum Pathol 7:451-454, 1976

39. Scully RE. Mitosis counting. I. Hum Pathol 7:481-482, 1976

40. Kempson RL. Mitosis counting. II. Hum Pathol $7: 482-483,1976$

41. Norris HJ. Mitosis counting. III. Hum Pathol 7:483-484, 1976

42. van Diest PJ, Baak JPA, Matze-Cok P, WisseBrekelmans ECM, Van Galen CM, Kurver PHJ, Bellot SM, Fijnheer J, Van Gorp LHM, Kwee WS, Los J, Peterse JL, Ruitenberg HM, Schapers RFM, Schipper MEI, Somsen JG, Willig AWPM, Arzens A Th. Reproducibility of mitosis counting in 2,469 breast cancer specimens: Results from the multicenter morphometric mammary carcinoma project. Hum Pathol 23:603-607, 1992 
43. Simpson JF, Dutt PL, Page DL. Expression of mitoses per thousand cells and cell density in breast carcinomas: A proposal. Hum Pathol 23:608-611, 1992

44. Baak JPA. Mitosis counting in tumors. Hum Pathol $21: 683-685,1990$

45. Ellis PSJ, Whitehead R. Mitosis counting-A need for reappraisal. Hum Pathol 12:3-4, 1981

46. Zuckman MH, Williams G, Levin HS. Mitosis counting in seminoma: An exercise of questionable significance. Hum Pathol 19:329-335, 1988

47. Ojanguren I, Ariza A, Llatjos M, Castella E, Mate JL, Navas-Palacios JJ. Proliferating cell nuclear antigen expression in normal, regenerative, and neoplastic liver: A fine-needle aspiration cytology and biopsy study. Hum Pathol 24:905-908, 1993

48. Fonseca I, Soares J. Proliferating cell nuclear antigen immunohistochemistry in epithelial-myoepithelial carcinoma of the salivary glands. Arch Pathol Lab Med 117:993-995, 1993

49. Kitamoto $M$, Nakanishi T, Kira S, Kawaguchi $M$, Nakashio R, Suemori S, Kajiyama G, Asahara T, Dohi $\mathrm{K}$. The assessment of proliferating cell nuclear antigen immunohistochemical staining in small hepatocellular carcinoma and its relationship to histologic characteristics and prognosis. Cancer 72: 1859-1865, 1993

50. Nielsen AL, Nyholm HCJ. Proliferating cell nuclear antigen in endometrial adenocarcinomas of endometrioid type correlated with histologic grade, stage, previous hormonal treatment, and survival. Hum Pathol 24:1003-1007, 1993

51. Delahunt B, Bethwaite PB, Nacey JN, Ribas JL. Proliferating cell nuclear antigen (PCNA) expression as a prognostic indicator for renal cell carcinoma: Comparison with tumor grade, mitotic index, and silver-staining nucleolar organizer region numbers. J Pathol 170:471-477, 1993

52. Horny H-P, Schumacher U, McCullagh P, Wehrmann $M$, Roche WR, Kaiserling E. Proliferation of reactive neoplastic human tissue mast cells: An immunohistochemical study using the antibody PC10 (anti-PCNA). J Pathol 170:265-270, 1993

53. Oda Y, Hashimoto $H$, Takeshita S, Tsuneyoshi M. The prognostic value of immunohistochemical staining for proliferating cell nuclear antigen in synovial sarcoma. Cancer 72:478-485, 1993

54. Pendleton N, Dixon GR, Burnett HE, Occleston NL, Myskow MW, Green JA. Expression of proliferating cell nuclear antigen (PCNA) in dysplasia of the bronchial epithelium. J Pathol 170:169-172, 1993

55. Roos G, Landberg G, Huff JP, Houghten R, Takasaki $Y$, Tan EM. Analysis of the epitopes of proliferating cell nuclear antigen recognized by monoclonal antibodies. Lab Invest 68:204-210, 1993
56. Coltrera MD, Skelly M, Gown AM. Anti-PCNA antibody PC10 yields unreliable proliferation indexes in routinely processed, deparaffinized, formalinfixed tissue. Appl Immunohistochem 1:193-200, 1993

57. McCormick D, Hall PA. The complexities of proliferating cell nuclear antigen. Histopathol 21: 591-594, 1992

58. McCormick D, Yu C, Hobbs C, Hall PA. The relevance of antibody concentration to the immunohistological quantification of cell proliferation-associated antigens. Histopathol 22:543-547, 1993

59. Isik FF, Ferguson $M$, Yamanaka E, Gordon D. Proliferating cell nuclear antigen - A marker for cell proliferation in autopsy tissues. Arch Pathol Lab Med 116:1142-1146, 1992

60. Start RD, Cross SS, Clelland C, Silcocks PB, Rogers K, Smith JHF. Delay in fixation does not affect the immunoreactivity of proliferating cell nuclear antigen (PCNA). J Pathol 268:197-199, 1992

61. Takahashi H, Oishi Y, Chuang S-S, Morii S. Effects of tissue fixation and processing on proliferating cell nuclear antigen (PCNA) immunohistochemistry. Acta Pathol Jpn 42:621-623, 1992

62. Hall PA, Levison DA, Woods AL, Yu CC-W, Kellock DB, Watkins JA, Barnes DM, Gillet CE, Camplejohn R, Dover R, Waseem NH, Lane DP. Proliferating cell nuclear antigen (PCNA) immunolocalization in paraffin sections: An index of cell proliferation with evidence of deregulated expression in some neoplasms. J Pathol 162:285-294, 1990

63. Leong AS-Y, Milios J, Tang SK. Is immunolocalization of proliferating cell nuclear antigen (PCNA) in paraffin sections a valid index of cell proliferation? Appl Histochem 1:127-135, 1993

64. Theunissen PHMH, Leers MPG, Bollen ECM. Proliferating cell nuclear antigen (PCNA) expression in formalin-fixed tissue of non-small cell lung carcinoma. Histopathology 20:251-255, 1992

65. Leach FS, Tokino $T$, Meltzer P, Burrell $M$, Oliner JD, Smith S, Hill DE, Sidransky D, Kinzler KW, Vogelstein B. p53 mutation and MDM2 amplification in human soft tissue sarcomas. Cancer Res 53:2231-2234, 1993

66. Cordon-Cardo C, Latres E, Drobnjak $M$, Oliva MR, Pollack D, Woodruff JM, Marechal V, Chen J, Brennan MF, Levine AJ. Molecular abnormalities of MDM2 and p53 genes in adult soft tissue sarcomas. Cancer Res 54:794-799, 1994

67. Florenes VA, Maelandsmo GM, Forus A, Andreassen A, Myklebost O, Fodstad O. MDM2 gene amplification and transcript levels in human sarcomas: Relationship to TP53 gene status. J Natl Cancer Inst 86:1297-1302, 1994 